\title{
The Polysemous Nature of Some Arabic Prepositions
}

\author{
Manal Mohamed Abdel Nasser \\ Department of English, Faculty of Arts, Assiut University, Egypt \\ E-mail: manal.hashem@art.au.edu.eg
}

Received: January 22, 2013 Accepted: February 18, 2013 Published: April 22, 2013

doi:10.5296/ijl.v5i2.3102 URL: http://dx.doi.org/10.5296/ijl.v5i2.3102

\begin{abstract}
The present study is a semantic approach that deals with the meaning of Arabic prepositions which is a complex issue due to their polysemous nature that they intentionally alternate with one another for rhetorical purposes. Basically, every preposition has one primary meaning and other secondary meanings which are, in a way or another, related together on the one hand and to the primary meaning on the other. The study is interested in investigating how the primary meaning of a preposition comprises the other secondary meanings and that they form a network of related meanings with the primary one acting as the centre or the basis of the other ones. The examples presented in the study are taken from both Classical and Modern Standard Arabic. The study concludes that Arabic prepositions are very important functional words which have polysemous nature and that through the notions of transitivity, implication and alternation, the meaning conveyed by a preposition varies to a wide range.
\end{abstract}

Keywords: Polysemy, Relatedness, Arabic prepositions, Transitivity, Alternation, Implication 


\section{Introduction}

This linguistic study is devoted to the Arabic language because of its importance "as the language of a major culture and of a major religion" (Comrie 1991: 4). Again, the study is devoted to 'prepositions' as the least tackled word class though they are most important to the structure and the semantics of a sentence. However, "a preposition is semantically empty as long as it appears alone but when it comes in a sentence it denotes a meaning in its neighboring element; however, it does not denote a time" (Hassan 2004:1/68) (translation mine). Moreover, prepositions in Arabic are subdivided according to their form into separable and inseparable and according to their type into original, redundant and quasi-redundant (See the Appendix for the phonemic symbols used in the transcription of Arabic forms).

The separable preposition is the one that has a free form which is not attached to the noun such as /mina/ 'from', /?ila/ 'to', /9an/ 'away from', /9ala/ 'on' and /fii/ 'in'. However, the inseparables are always bound or rather prefixed to the nouns such as /bi-/ 'of' and /li-/ 'for'. As for the original preposition, it always adds a new meaning to the sentence in which it appears and is always connected with the verb or its regent. The redundant preposition does not add a new meaning to the sentence and does not have a regent. It is used only to confirm the meaning of the sentence like:

(1) lasta 9alayhim bi-muSayTir (Qur'an 88: 22)

Thou art not one to manage (men's) affairs.

(All Qur'anic translations are taken from Ali (1938))

The quasi-redundant, on the other hand, adds a new meaning which is either a meaning of 'decrease' or 'increase', but does not have a regent like /rubb-a/ 'maybe' as in:

(2) rubb-a Daarrat-in naafi9at-un

Maybe what seems harmful can be beneficial.

Hassan (1996: 2/434) explains the function of an original preposition in two ways. First, it adds a new detailed meaning to the sentence. Second, it links the regent (the verb) with the following noun as follows:

\section{(3) jaa?-a muћammad-un}

\section{Muhammad came.}

This sentence arises many urgent questions in the minds. Simply, one is eager to know the beginning and the end of Muhammad's route. So, if /mina/ 'from' is used; it adds a new subsidiary meaning of the starting point of his motion and if /? ila/ 'to' is used, it denotes the end of the journey. That is the preposition adds, in the two cases, two new meanings: one for 'the beginning' and the other for 'the end or the termination'. However, these meanings are only understood when the preposition appears in the sentence, but when it appears alone, it doesn't convey a meaning.

The second function of a preposition in a sentence is to make a link between the verb that 
precedes it and the noun that follows it (Ibid). In other words, it acts as a bridge by means of which the verb passes on to an object. In this way, the genitive noun that follows the preposition is construed as an object of the verb, literally and virtually but not actually. And this is one of the ways in which the intransitive verb becomes transitive and the mono-transitive verb becomes ditransitive. Wright (1964: 2/46) states that "only careful study and the use of the dictionary can teach the learner whether a verb is construed with the accusative, or with a preposition, or with both; and, if more than one construction be admissible, what are the different meanings that the verb assumes." Accordingly, the difference between the actual object and the virtual object is that the former is directly connected with the verb and is always in the accusative case, while the latter is only connected to the verb by means of a preposition and is always in the genitive case (Hassan 1996: 2/439).

A central idea to the topic of the present study is that "prepositions are sometimes described by the Arabs as being interchangeable" (Haywood \& Nahmad 1982: 413). This implies that every preposition has multiple distinct meanings which are often related and which "constitute a semantic network organized with respect to a primary sense" (Tyler \& Evans 2003: 2-3). This polysemous nature of Arabic prepositions is linguistically justified by two linguistic phenomena: rendering intransitive verbs transitive and implication which are fully explained in the next part.

\section{Theoretical Framework}

Hassan (1996: 2/159) discusses the use of an original preposition to change the verb category from intransitive to transitive. In such a case, the preposition helps the verb to pass on its effect to the following noun which turns, virtually, to be an object of this verb. The verb |xaraj-a/'to get out' represents a good example:

(4) a- xaraj-a r-rajul (intransitive verb)

The man got out.

b- xaraj-a r-rajul-u mina l-manzil-i (transitive verb)

The man got out of the house.

In the above example, /mina/ 'from' denotes the beginning or starting point of the action and /l-manzil/'the house' is virtually the object.

Hassan (Ibid: 161) also adds that this function of passing on the effect of a verb to an object is not restricted to a specific preposition. This means that any preposition can be chosen to fulfill this function as long as it conveys the intended meaning. For example, the verb |xaraj-a/ 'to get out' in the previous example can be used with a different preposition to convey a different meaning as follows:

(5) xaraj-a r-rajul-u ?ila l-9amal

The man got out to work. 
In such a case, /?ila/ 'to' denotes the 'termination' of the action and /l-9amal/ 'the work' is virtually the object. That is to say, the use of prepositions varies according to the meanings one wants to convey.

Another crucial point that is discussed by Hassan (Ibid: 169-185) is the notion of /?at-taDmiin/ 'implication'. It is when a verb implies the meaning of another and consequently acquires its same effect concerning transitivity. That is if the implied verb is intransitive, the acting verb becomes intransitive and if the implied verb is transitive, the acting verb becomes transitive.

(6) ?ana? a9zim-u s-safar-a

I intend to travel.

In this example, /s-safar-a/ 'travel' is the object of the verb /?a9zim-u/ 'to intend' which is originally intransitive. The reason it becomes transitive, in the above example, is that it implies the meaning of the verb /? anwi/'to intend' which is transitive. Alone, /? a9zim-u/ 'to intend' needs a preposition to pass on its effect to an object as follows:

(7) ?ana ?a9zim-u 9ala s-safar-i

I intend to travel.

The opposite case is also true. That is a transitive verb may be used intransitively when it implies the meaning of an intransitive verb. In the following examples, the verb /sami9-a/ 'to listen', which is basically transitive, is used in the two ways:

(8) qad sami9-a llaahu qawl-a llatii tujaadil-u-ka fii zawj-i-haa wa-taštakii ?ila llaah-i

(Qur'an 58: 1)

God has indeed heard (and accepted) the statement of the woman who pleads with thee concerning her husband and carries her complaint (in prayer) to God.

(9) wa-in yaquul-uu tasma9 li-qawl-i-him (Qur'an 63: 4)

and when they speak, thou listenest to their words.

In example (8), /sami9-a/ 'to listen' is transitive and /qawl-a/'saying' is its object. In example (9), however, /tasma9/ 'listens' is used intransitively and is followed by a preposition + a noun in the genitive. This is because it implies the meaning of the verb /? anSat-a/'to listen carefully' which is intransitive and needs a preposition to pass on its effect to the following noun. In this example, the preposition / $l i-/$ 'for' and the noun it governs in the genitive stand virtually for the object.

/?at-taDmiin/ 'implication' is usually confirmed by analogy (Hassan 1996: 2/171). That is constructions are judged against the standard usage of the Arabs in order to understand the implied meaning that justifies the construction in question. Linguists usually consult many sources in their analogies like the Glorious Qur'an, Prophet Muhammad's sayings, the speech 
of the Arabs and the poetry written by eminent Arab poets. The one that is in effect in the present study is the Glorious Qur'an.

It is worth mentioning that Arab grammarians show us how to distinguish the transitive from the intransitive. Ibn Aqiil (2003: 1/484) explains that if the verb is suffixed by an attached pronoun like / $\mathrm{haa} /$ which refers back to a noun other than /?al-maSdar/'the verbal noun' and the sentence sounds acceptable, then the verb is said to be transitive. The following example illustrates this idea.

(10) ?al-ћujrat-u naZZaf-tu-haa

I cleaned the room.

In this example, the sentence structure is acceptable and this indicates that /naZZaf-al 'cleaned' is a transitive verb.

As for intransitive verbs, Hassan (1996: 2/154-156) classifies them into categories. The following list presents the most common ones:

1 -Verbs denoting a personal attribute corresponding to the form [fa9ul-a] like /jabun-a/'to be a coward'.

II-Verbs denoting something temporary like /mariD-a/ 'to be sick', /fazi9-a/'to be frightened' and / $\hbar a z i n-a /$ 'to be sad'.

III-Verbs denoting colour like /?iћmarr-a/ 'to become red'.

IV-Verbs corresponding to the form [if9alall-a] like /?iqša9arr-a/'to tremble'.

V-Verbs corresponding to the form [ $f a 9 a l-a]$ like /mala? - a/ 'to fill' provided that their

descriptive forms correspond to the form [fa9iil] like /malii?/ 'full'.

VI-Verbs corresponding to the form [?infa9al-a] like /?imba9ae-a/ 'to emit'.

VII-Quadriliteral verbs affixed by a letter or two like /tadahraj-a/ 'to roll'.

\section{Discussions and Results}

Studying the prepositions in any language is a perplexing issue which is, very much, far from being straightforward. An Arabic preposition, the target of the present study, entails a number of various senses. The present paper presents prepositions in two ways. The former subdivides them into primary and secondary senses, while the latter includes the cases in which a certain preposition alternates with other prepositions. Basically, every single preposition has one primary meaning associated with it. It is the one we promptly recall whenever we come across it. Around this primary or central meaning revolve a number of secondary meanings which, as it seems, derive from it forming a network of related meanings. In short, the present study proves the flexibility and eloquence of the Arabic language and obviously shows the alternation of prepositions in the place of one another.

A key notion to the topic of the present study is polysemy. One major criterion of polysemy 
is relatedness of meaning (Lyons 1977: 2/551). That is when one single lexical item has several related meanings, it is said to be polysemous. And this is exactly the case of Arabic prepositions. The network idea proposed in this paper is based on the idea of relatedness. The primary and secondary meanings are related to one another. Similarly, the secondary meanings of the same preposition are also related by means of being grouped together under the umbrella term alternation. The different senses of the same preposition alternate with different prepositions. Yet they are still related by means of playing the same role, i.e. alternation. The following part explains the polysemous nature of some Arabic prepositions.

\section{1 /mina/ 'from, of'}

According to Hassan (1996: 2/458-465), /mina/ 'from' has eleven meanings. Its primary sense is to denote 'commencement' or the 'starting point' in place as follows:

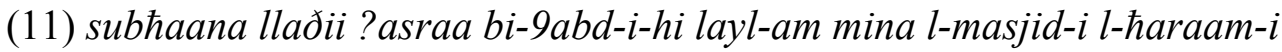

?ila l-masjid-i l-?aqSa (Qur'an 17: 1)

Glory to (God) who did take His servant for a journey by night from the Sacred Mosque to the Farthest Mosque.

(12) fahab lii mil ladun-ka waliyyaa (Qur'an 19: 5)

So give me an heir as from Thyself.

Ibn Aqiil (2003: 2/18) extends this primary sense to include the starting point in time as well:

(13) lamasjidun ? ussisa 9ala t-taqwaa min? awwali yawmin ?aћaqqu ?an taquuma fiih

(Qur'an 9: 108)

There is a mosque whose foundation was laid from the first day on piety; it is more worthy of thy standing forth (for prayer) therein.

The second sense of /mina/'from' is as a partitive particle:

(14) wa-mina n-naas-i may yujaadil-u fi llaah-i (Qur'an 22: 3)

And yet among men there are [some] such as dispute about God (The addition is mine)

(15) wa-razaq-a-kum mina T-Tayyibaat-i (Qur'an 16: 72)

And provided for you sustenance of the best

Two nouns are usually involved in this case. The one which is governed by /mina/ 'from' in the genitive case and which immediately follows it represents the source or the whole, while the other noun in the context, wherever it occurs, represents the part. In example (15), this noun is implied and it refers to /? ar-rizq/ 'sustenance'. Obviously, the noun that represents the whole or the source from which the part is taken stands for a starting point. In this sense, the use of /mina/ 'from' as a partitive particle is a secondary sense which is related to its primary sense. 
The third sense of /mina/'from' is to indicate the genus:

(16) fa-jtanib-u r-rijs-a mina l-?aweaan-i (Qur'an22: 30)

but shun the abomination of idols

In this sense the part-whole relation discussed in the second sense is reversed. In the present case, the noun that indicates the source or the whole comes before /mina/ 'from', while the one that indicates the part or the genus comes after it. The idea that the part usually springs from the whole or the source corresponds to the notion of commencement or starting point. Accordingly, this sense is another secondary sense of /mina/ 'from' and is also related to its primary sense.

Obviously, the meeting point of the first three senses of /mina/ 'from' is the idea of 'commencement' or the 'starting point' or being the source of something. This idea is stated openly in the primary sense and is understood in the secondary senses through the part-whole relation. In this way, /mina/ 'from' is polysemous and its first three senses are linked by the notion of relatedness of meaning. Together, these senses comprise a network of the preposition, /mina/'from'. Interestingly, they come together in the following verse:

(17) wa-yunazzil-u mina s-samaa?-i min jibaal-in fii-haa mim barad-in (Qur'an 24: 43)

And He sends down from the sky mountain masses (of clouds) wherein is hail

Ibn ManZur (1981: 6/4282) comments on the three occurrences of /mina/ 'from' specifying the first for commencement, the second as a partitive and the third as a particle indicating the genus.

The fourth sense of /mina/ 'from' is its use for confirmation. In this sense, it is redundant. To be used in this sense, /mina/ 'from' must meet two conditions (Hassan 1996: 2/461-2). The first is to appear after a negative or interrogative particle. The second is that the noun following /mina/'from' is indefinite and is virtually vowelled by a final /i/. In this way, /mina/ 'from' in (18) below meets Hassan's two conditions as it occurs after the negative particle /hal/ 'do' and is followed by an indefinite noun in the genitive case, /fuTuur-in/ 'flaw':

(18) fa-rji9 il-baSar-a hal taraa min fuTuur-in (Qur'an 67: 3)

So turn thy vision again: seest thou any flaw?

In the above example, because /mina/'from' is redundant, /fuTuur/'flaw' is actually the object of the verb /taraa/ 'to see' and is virtually governed by /mina/ 'from' in the genitive. /mina/ 'from' is used in this context to indicate that man fails to find any defect in the creation of Allah.

The remaining seven senses of the polysemous /mina/'from' are linked together by the idea of alternation and are summed up in figure 1. 


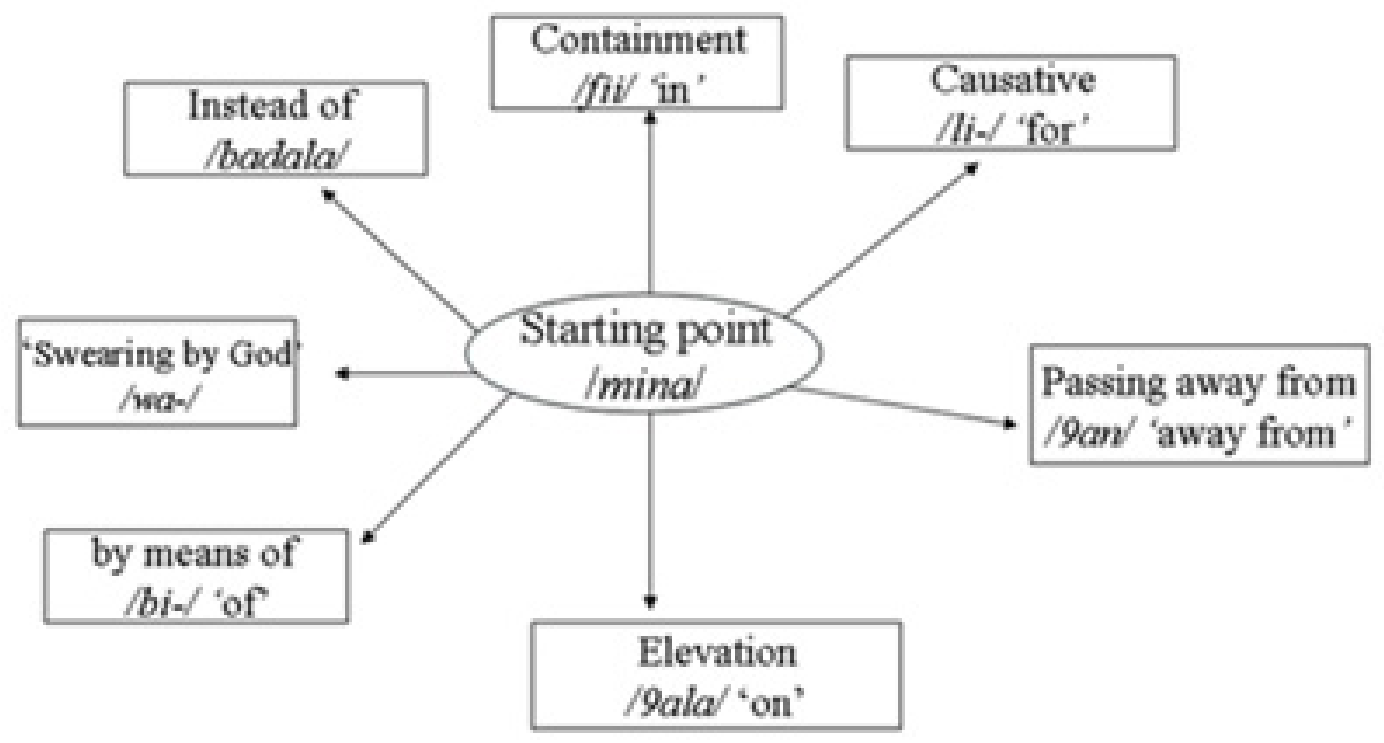

Figure 1. Some secondary senses of /mina/'from'

In this figure, every arrow leads to an abstract meaning which is conveyed by alternating with some other preposition or particle. The first meaning is the meaning of 'containment':

(19) wa-tanhituuna mina l-jibaal-i buyuutan faarihiin (Qur'an 26: 149)

And ye carve houses out of (rocky) mountains with great skill.

In this verse, /mina/ 'from' alternates with / fii/ 'in' and denotes 'containment'. This is because the verb/tanhituuna/ 'to carve' implies the meaning of the verb/tattaxiduuna/ 'to take/ to make use' which collocates with /mina/'from'. This usage is actually based on the citation of another verse of the Glorious Qur'an as an authority on the Arabic language: /wa-ttaxid-uu mim maqaam-i ?ibraahiim-a muSalla/ (Qur'an 2: 125) 'And take ye the station of Abraham as a place of prayer'.

As for the second meaning, /mina/ 'from' alternates with the preposition /li-/ 'for' and denotes causativity:

(20) mim-maa xaTii?aat-i-him ?ugriq-uu fa-?udxil-uu naar-an (Qur'an 71: 25)

Because of their sins they were drowned (in the flood), and were made to enter the fire (of punishment).

According to Hassan (1996: 2/465), /maa/ is redundant, in the above example, and does not affect either the meaning or the function of /mina/ 'from'.

In the third meaning, /mina/ 'from' replaces /9an/ 'away from/ of' to denote the abstract meaning of 'passing away from':

(21) laqad kunt-a fii gaflat-im min haðaa (Qur'an 50: 22)

(It will be said:) thou wast heedless of this

/gaflat-im/ 'inattention' in the above example means /bu9d/'remoteness' and the Arabs usually 
say /ba9iid 9an/ and not /ba9iid min/.

The fourth abstract meaning expressed by /mina/ 'from' in the above figure is the meaning of 'elevation'. In this sense, /mina/ 'from' alternates with /9ala/ 'on' as shown in the following verse:

(22) wa-naSarnaa-hu mina l-qawm-i llaðiina kaððab-uu bi-?aayaat-i-naa

(Qur'an 21: 77)

We helped him against people who rejected Our signs

In this verse, /mina/ 'from' means $/ 9 \mathrm{ala} /$ 'on' and the reason it appears in this context is that the verb /naSar-a/ 'to help', implies the meaning of the verb/mana9-a/ 'to prevent' which collocates with /mina/'from'. This usage is also based on the citation of another verse of the Glorious Qur'an as an authority on the Arabic language: /yaa ?abaa-naa muni9-a min-na l-kayl-u/ (Qur'an 12: 63) 'O our father! No more measure of grain shall we get'.

The fifth abstract meaning of /mina/ 'from' is the one which entails 'by means of' in which /mina/ 'from' alternates with the preposition /bi-/ 'of'. In this case, as Hassan (1996: 2/464) suggests, the noun following /mina/ 'from' stands for the means or instrument used in fulfilling the action of the verb.

(23) yulqi r-ruuh-a min ?amr-i-hi (Qur'an 40: 15)

By His command doth He send the spirit (of inspiration).

The sixth abstract meaning of /mina/'from' is used in 'swearing by God'. In this sense, /mina/ 'from' alternates with the particle /wa-/ 'and' which is used in swearing. It is usually followed by the Glorious name, /? allaah/ 'God' and its first consonant, $/ \mathrm{m} /$, is vowelled either by /u/ or /i/ as in /mina llaah-i/ 'I swear by God' and /muna llaah-i/ 'I swear by God' (Hassan 1996: $2 / 465)$.

(24) mina llaah-i la-?usaa9id-anna l-miskiin-a

I swear (by the name of Allah) to help the poor.

The seventh abstract meaning of /mina/'from' is the one which means /badala/ 'instead of' as it is the case in the following verse:

(25) wa-law našaa?-u la-ja9al-naa min-kum malaa?ikat-an fi l-?arD-i yaxlufuun

(Qur'an 43: 60)

And if it were Our Will, We could make angels from amongst you, succeeding each other on the earth.

In almost all the above-mentioned senses of /mina/ 'from' which are summed up in figure 1, the primary sense of /mina/ 'from' exists side by side with the additional secondary sense which is acquired every time in a new context. When /mina/ 'from' alternates with /fii/'in', it conveys the meaning of containment in /l-jibaal-i/ and, at the same time, /l-jibaal-i/is still the 
starting point of /tantituun- $a /$. Therefore, the two senses, the primary and the secondary, are semantically linked. In the second sense, /mina/ 'from' alternates with /li-/ 'for' and acts as a causative. Yet, it conveys the meaning that /xaTii?aat-i-him/ represents the commencement of the action of being drowned. So, it clarifies the cause and the starting point simultaneously. In the third sense, though /mina/ 'from' denotes 'passing away from', it entails the starting point, in time, of the clear vision when Prophet Muhammad (PBUH) could see "the spiritual world" (Ali 1938: 1413). In the fourth sense, /mina/ 'from' alternates with /9ala/ 'on' and conveys the abstract sense of 'elevation'. However, as a result of implication, it implies the meaning of /mana9-a/to prevent' which collocates with /mina/ 'from' and in this way, the meaning of 'commencement' or 'starting point' is echoed. In the fifth sense, /mina/ 'from' conveys the primary meaning of source and the secondary meaning of being an instrument at the same time as reflected in /min ?amr-i-hi/'out of his command'. In the sixth sense, /mina/ 'from' alternates with /wa-/ 'and' and functions as a particle of 'swearing by God'. In the seventh sense, /mina/ 'from' conveys two meanings simultaneously. Though, it conveys the meaning of /badala/ 'instead of', it retains the meaning of source or starting point which is made clear by means of the attached pronoun /-kum/. In this way, all the secondary senses of Imina/'from' are linked together by the primary sense, on the one hand, and by the notion of alternation, on the other.

\section{2 /?ila/ 'to'}

Arab grammarians agree that the primary sense of /?ila/ 'to' is to indicate 'termination' or 'ending point' of place and time (Al-Rumani 2008: 128; Hassan 1996: 2/468; Al-Maliqi 1394 $\mathrm{H}: 80)$. It is the most common sense with which it is well-known and used. In other words, it is the inherent sense of this preposition. Example (11) above clarifies the idea of the ending point of place, while the ending point of time is clarified by the following sense:

(26) Oumma ?atimm-u S-Siyaam-a ?ila l-layl-i (Qur'an 2: 187)

Then complete your fast till the night appears.

This particular example is among the evidences used in the disputes of the Arab grammarians who advocate the idea that what follows /?ila/ 'to' is not included in what precedes it (Hassan 1996: 2/468 and Al-Maliqi $1394 \mathrm{H}$ : 80) unless there is some sort of association or link between them. Then, according to the above verse, the night is not included in the fasting period.

However, if the opposite case is true, i.e. if the noun that follows /? ila/ 'to' is included in what precedes it, /?ila/'to' in this case means /ma9a/ 'with' and denotes 'company' (Al-Maliqi 1394 H: 83):

(27) qaal-a laqad Zalamak-a bi-su?aal-i na9jatik-a ?ila ni9aaj-i-h-i (Qur' an 38: 24)

(David) said: he has undoubtedly wronged thee in demanding thy (single) ewe to be added to his (flock of) ewes.

The third meaning expressed by /?ila/ 'to' is that of 'containment'. The following verse 
clarifies this meaning:

(28) Oumma yajma9ukum ?ila yawm-i-l-qiyaamat-i (Qur'an 45: 26)

then He will gather you together for the Day of Judgment

In fact, the second and the third senses of /? ila/ 'to' are secondary senses which are in a way or another interrelated with the primary sense of 'termination' or 'ending point'. In (27) above, the meaning of company itself denotes termination. If the single ewe is added to the flock of ewes, it ends with them. Again in (28), though /? ila/ 'to' means 'containment', it implies that the Day of Judgement is the termination of human life on earth.

Moreover, there is still a fourth sense of /?ila/ 'to'. It is the sense of 'specification' in which /?ila/'to' alternates with the preposition /li-/ 'for' as seen in the following verse:

(29) wa-l-?amr-u ?ilay-ki fa-nZur-ii maaðaa ta?mur-iina (Qur'an 27: 33)

But the command is with thee; so consider what thou wilt command.

Here, /?ilay-ki/ 'with thee' means your word is final and unquestionable. In this sense, it is considered a secondary sense derived from the primary sense of 'termination'. In this way, /?ila/ 'to' has got four inherent senses: one primary and three secondary.

Hassan (1996: 2/470) cites another meaning of /?ila/ 'to' as a partitive:

(30) Šarib-a l-9aaTiš-u fa-lam yartawi ?ila l-maa?-i

The thirsty man drank water but he did not satisfy his thirst.

Eisaa (2011: 380-381) explains this uncommon usage of /?ila/ 'to' on the ground that /?aZ-Zama?/ 'thirst' is the cause of /?al-?irtiwaa?/ 'thirst-satisfaction'. This causative link results in the implication of the verb /yartawi/ 'to satisfy one's thirst' of the meaning of the verb /yaZma?/ 'to be thirsty' so that it collocates with /?ila/ 'to' instead of /mina/ 'from'. Interestingly, /?al-?irtiwaa/ 'thirst-satisfaction' is an abstract termination point of /?al-9aaTiš-u/ 'the thirsty person' and reaching the water source is a concrete termination point of the thirsty person. Therefore, on both levels, abstract and concrete, the sense of termination which is the primary sense of /?ila/ 'to' is obvious in the present example and in the use of /?ila/ 'to' as a partitive.

\section{3 /fii/'in, within':}

The preposition /fii/ 'in' is used to express a variety of senses, the primary one is that of 'containment' (Hassan 1996: 2/507-508). The noun that follows /fii/ 'in' is usually the container of what precedes it. The following verses clarify this meaning:

(31) wa-?alqaa fi l-?arD-i rawaasiya ?an tamiida bikum (Qur'an 16: 15)

And He has set up on the earth mountains standing firm, lest it should shake with you.

(32) laa taqtul-un yuusuf-a wa-?alq-uu-hu fii gayaabat-i l-jubb-i (Qur'an 12: 10)

Slay not Joseph, but if ye must do something, throw him down to the bottom of the well. 


\section{Macrothink}

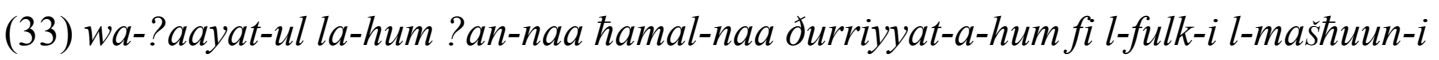

(Qur'an 36: 41)

And a sign for them is that We bore their race (through the flood) in the loaded ark.

Around this primary sense, there are seven other secondary meanings which are connected in some way to the idea of 'containment' either at the concrete or the abstract level. Figure 2 summarizes these senses which are explained one by one in the following paragraphs.

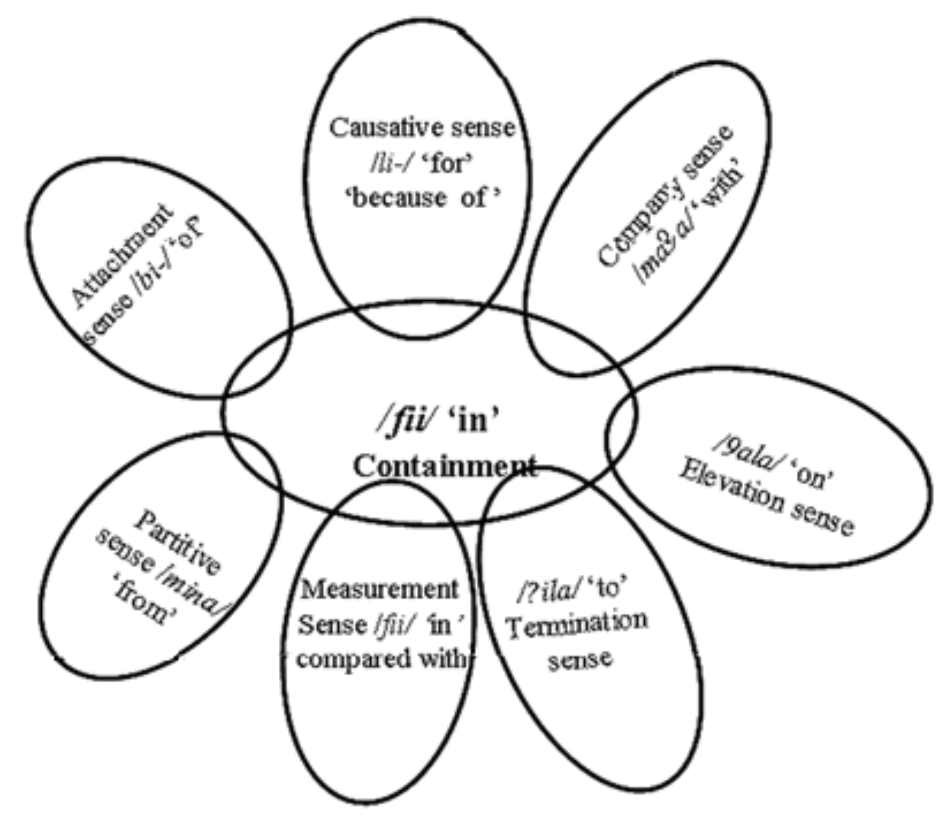

Figure 2. The primary and secondary senses of /fii/ 'in'

(34) qaal-at fa-ðaalik-unna llaðii lum-tunna-nii fiih (Qur'an 12: 32)

She said: there before you is the man about whom ye did blame me!

This example indicates that the ladies' reproach and dispute are centered on Zulaixa's (Aziz's wife) passion towards Joseph and on his innocence and firm resistance to guilt as if this issue was figuratively the container in which all these disputes and talks are poured. Though /fii/ 'in', here, means /li-?ajl/'for' or /bi-sabab/ 'because of', it still entails the abstract meaning of 'containment' as part of its meaning and it alternates with the preposition /li-/ 'for'.

(35) rabbi fa-laa taj9al-ni fi l-qawm-i Z-Zaalimiin (Qur'an 23: 94)

Then, O my Lord! put me not amongst the people who do wrong!

It is clear that verse (35) is a supplication not to be in the company of those people who deserve punishment. /fii/ 'in' means 'with' and it signifies the meaning of 'company'. Yet, to be in the company of some people is to be one of them or rather to be contained with them in one place. And this is how / $f$ ii/ 'in' indicates containment plus company simultaneously.

(36) wa-la-?uSallib-anna-kum fii juðuи9-i n-naxl-i (Qur'an 20: 71) 
and I will have you crucified on trunks of palm-trees

In (36), /fii/ 'in' means / $/ 9 \mathrm{ala} /$ 'on' and it indicates the meaning of 'elevation' since the crucified are placed on the trunks of the trees. At the same time, the crucified are found on the surface of the trunks to which they are attached. Accordingly, those trunks, though not deep, represent flat containers of the crucified. On this basis, the sense of /fii/'in', here, entails the abstract meaning of 'containment'.

(37) fa-radd-uu ?aydiy-a-hum fii ?afwaah-i-him (Qur'an 14: 9)

but they put their hands up to their mouths

In (37), /fii / 'in' alternates with /?ila/ 'to' which entails the sense of 'termination' or 'end'. In this example, the word /? afwah-i-him/ 'their mouths' represents the termination point and this recalls the meaning of /?ila/'to'. Moreover, by doing so, those people actually put their hands in their mouths in order not to talk and in this sense, their mouths are containers of their hands. Moreover, the verb /radd-a/ 'to restore' collocates with /? ila/ 'to' but not with /fii/ 'in' according to a different citation of the Glorious Qur'an:

(38) ?in-naa raadd-uu-hu ?ilay-ki (Qur'an 28: 7)

For We shall restore him to thee

Therefore, the verb / radd-a/ 'to restore' passes on its effect to a second object by means of the preposition /? ila/ 'to' and /fii/ 'in' in (37) alternates with /? ila/ 'to' to indicate 'termination' and 'containment' at the same time.

(39) wa-?adxil yad-a-ka fii jayb-i-ka taxruj bayDaa?-a min gayr-i suu?-in fii tis9-i ?aayaat-in ?ilaa fir9awna wa- qawm-ih (Qur'an 27: 12)

Now put thy hand into thy bosom, and it will come forth white without stain (or harm): (these are) among the nine signs (thou wilt take) to Pharaoh and his people.

Verse (39) cites the second miracle of Moses and indicates that this miracle together with the one mentioned earlier in this Surah are among the nine Signs of Moses to his people. This verse again indicates the meaning of / fii/ 'in' as a partitive which alternates with the partitive /mina/'from'. Because the part is usually contained in the whole, the above sense of /fii/'in' is that of 'containment'.

(40) naluuð-u fii ?umm-in la-naa (Ibn ManZur 1981: 5/3505)

We take refuge in the arms of our mother.

In (40), /naluud-u/ collocates with /bi-/ 'of' not with /fii/ 'in'. /fii/ 'in', in this example, alternates with $/ b i$-/ 'of' and conveys the meaning of 'attachment'. Obviously, when a child is scared and resorts to his/her mother for protection, he/she usually holds her firmly in the same way the crucified in example (36) above are attached to the trunks of the trees. Accordingly, together with the sub-meaning of 'attachment', the abstract sense of 'containment' is obviously felt in the meaning of / fii/'in' in the present case. 


\section{Macrothink}

International Journal of Linguistics

ISSN 1948-5425

2013, Vol. 5, No. 2

Interestingly, Hassan (1996: 2/507-508) cites an interesting sense of / fii/'in' as a particle used in comparison. It entails the meaning of measurement or analogy which is conveyed in the following verse:

(41) fa-maa mataa9-u l-hayaat-i d-dunyaa fi l-?aaxirat-i ?illaa qaliil (Qur'an 9: 38)

But little is the comfort of this life, as compared with the Hereafter.

To make the idea in verse (41) more tangible, one has to imagine /mataa9- $u$ l-hayaat- $i$ $d$-dunyaa/ as a small container which is placed in /l-?aaxirat-i/ that is supposed to be a big container. The actual act of containing one in the other clarifies the big difference between them and proves that the former to the latter is like a drop compared with a great ocean. 'Containment' here is the means and the end. Through containment, we measure the difference and measurement is based on containment. That is why this sense of /fii/ 'in' is an inherent secondary sense.

One concludes from the previous discussion of the various senses of the preposition /fii/ 'in' that the sense of 'containment' is the primary and inherent sense of / fii/'in' and that even when it is used to denote some other meaning as a secondary sense, it still retains the meaning of its primary sense inherent in some other deeper layer of meaning.

\section{4 /9ala/ 'on, over, above'}

Arab grammarians agree that the primary sense of $/ 9 \mathrm{ala} /$ 'on' is the sense of 'elevation' (Al-Rumani 2008: 122; Hassan 1996: 2/509; Al-Maliqi 1394 H: 372) which appears in the following verse:

(42) ?ar-rahmaan-u 9ala 1-9arš-i stawaa (Qur'an 20: 5)

(God) Most Gracious is firmly established on the throne (of authority).

This primary sense is extended to comprise five other secondary senses forming together a network of six inherent senses of the same preposition as shown in figure 3 below:

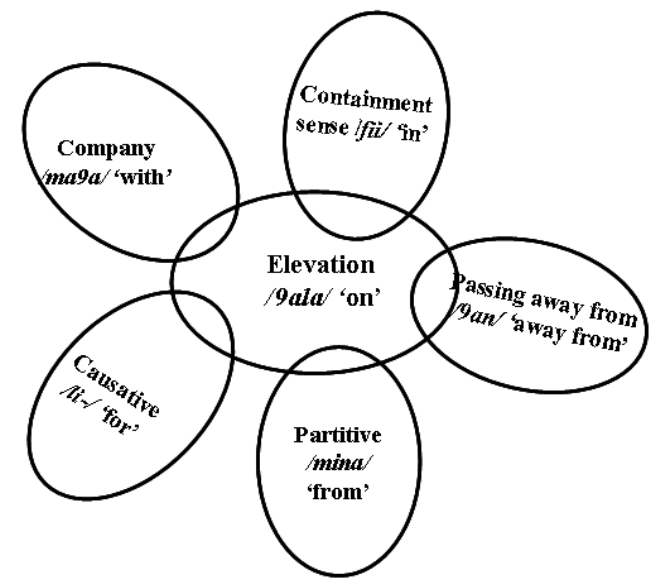

Figure 3. The primary and secondary senses of /9ala/ 'on' 
(43) wa-daxal-a l-madiinat-a 9alaa ћiin-i gaflat-im min ?ahl-i-haa (Qur'an 28: 15)

And he entered the city at a time when its people were not watching.

$19 \mathrm{ala} /$ 'on' in this verse alternates with / $\mathrm{fii} /$ 'in' and it entails the sense of 'containment'. This is because, according to another citation of the Glorious Qur'an, the verb /daxal-a/ 'to enter' collocates with / fii/'in' and not with/9ala/'on' as seen in the following example:

(44) yaa ?ayyuha llaðiina ?aaman-u dxul-uu fi s-silm-i kaaffah (Qur'an 2: 208)

O ye who believe! enter into Islam whole-heartedly.

It is worth mentioning that 'containment' implies 'elevation' since the contents of something may accumulate and pile up on one another which means that some parts are physically higher than other parts. Eisaa (2011: 397) states that "the meaning of containment implies the abstract meaning of elevation of both time and place."

As for the sense of 'passing away from', Hassan (1996: 2/510) cites the following example:

(45) ?iðaa raDiy-a 9alayya l-?abrar-u gaDib-a l-?ašraar-u

When the good are pleased with me, the evil get angry.

In this example, /9alayya/ means /9annii/ and it stands for the sense of 'passing away from' something. This sense is connected with the primary sense of 'elevation' because passing away from something implies being elevated above it. And this justifies the alternation between /9ala/'on' and /9an/'away from'.

(46) wa-?inna rabb-a-ka la-ðuu magfirat-in li-nnaas-i 9alaa Zulm-i-him. (Qur'an 13: 6)

But verily thy Lord is full of forgiveness for mankind for their wrong-doing.

(47) wa-?aata l-maal-a 9alaa ћubb-i-hi (Qur'an 2: 177)

. . . and gives his wealth, in spite of love for it. (Al-Hilâli \& Khân 1417 H: 35)

In (46) and (47), /9ala/ 'on' alternates with /ma9a/ 'with' to indicate the abstract meaning of 'company'. However, the abstract sense of 'elevation' is still retained implicitly in the meaning of the two verses, particularly in the first part, that precedes /9ala/ 'on'. In (46), the meaning of /magfirat-in/ 'forgiveness' is elevated above the meaning of /Zulm-i-him/ 'their wrong-doing'. Again in (47), /?aata l-maal-a/ 'gives his wealth' is also elevated above the meaning implied in / $\hbar u b b-i-h i /$ 'its love'. This is how the secondary sense of 'company' is connected with the primary sense of 'elevation'.

(48) ?inna llaah-a STafaa ?aadam-a wa-nuuh-an wa-?aal-a ?ibraahiim-a wa-?aal-a

9imraan-a 9ala l-9aalamiin-a (Qur'an 3: 33)

God did choose Adam and Noah, the family of Abraham, and the family of 'Imran above all people. 
This verse presents the fourth secondary meaning of $/ 9$ ala/ 'on'. In this context, $/ 9$ ala/ 'on' alternates with /mina/'from', the partitive. This is because /STafaa/ passes on its effect to the second object by means of the preposition /mina/'from' and this is based on a citation by Ibn ManZur (1981: 4/2468) in which he cites Prophet Muhammad (peace be upon him) as /Safwat-u llaah-i min xalq-i-hi wa-muSTafaa-hu/ 'God's chosen one from among all humanity'. So, /9ala/'on', here, equals /mina/'from' and entails partitivity.

However, Rashid (1996: 342) presents a justification of the use of /9ala/'on' in (48) from the point of view of implication. He cites that the verb /STafaa/ 'to choose' implies the meaning of the verb /faDDal-a/ 'to prefer' which collocates with /9ala/ 'on'. That is why it adopts the same preposition. Yet, if one chooses to adopt this explanation, the meaning of $/ 9 \mathrm{ala} /$ 'on' is altered from its secondary sense as a partitive to its primary sense of 'elevation'.

There is still a fifth meaning of /9ala/ 'on' as a causative particle and this meaning appears in (49) below:

(49) li-tukabbir-u llaah-a 9alaa maa hadaa-kum (Qur'an 22: 37)

that ye may glorify God for His guidance to you

In this sense, /9ala/ 'on' alternates with the preposition /li-/ 'for' and entails the meaning of cause or justification. Eisaa (2011: 399) states that this alternation is due to the notion of implication because the verb /tukabbir-uu/ 'to glorify' implies the meaning of /taškur-uu/ 'to thank' and adopts its same preposition. In sum, the abstract meaning of 'elevation' is represented by /maa hadaa-kum/ 'His guidance to you' which stands for the cause of /li-tukabbir-uu/ 'that you may glorify'. And this is how this secondary meaning of /9ala/ 'on' as a causative particle is related to its primary sense of 'elevation'.

\section{5 /9an/ 'off, away from, from'}

19an/ 'away from' has nine senses, one primary and eight secondary as shown in figure 4 below. It is mainly used to entail 'passing away from' (Al-Rumani 2008: 107; Hassan 1996: 2/513; Al-Maliqi $1394 \mathrm{H}$ : 367) which is its primary, inherent and widely used sense. This sense is clear in the following examples:

(50) 9afa llaah-u 9an-ka (Qur'an 9: 43)

God give thee grace!

(51) wa-man yargab-u 9am millat-i ?ibraahiim-a ?illaa man safih-a nafs-a-hu

(Qur'an 2: 130)

And who turns away from the religion of Abraham but such as debase their souls with folly?

In both (50) and (51), /9an/ 'away from' stands for the meaning of 'passing away from' but in (50) it is in the form of God's forgiveness while in (51) it is in the form of deviating from the right path (Ibn Kathir: 1/185). 
Besides 'passing away from', /9an/ 'away from' entails other secondary senses. In some contexts, it means / $\mathrm{ba} 9 \mathrm{da} /$ 'after' which indicates time as illustrated in the following verse:

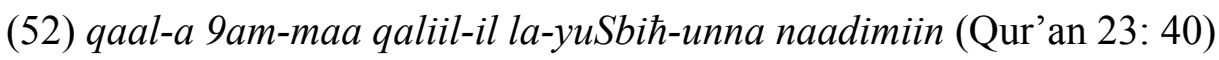

(God) said: "In but a little while, they are sure to be sorry!"

Though this sense is secondary, it is inherent and closely related to the primary sense since it implies a sense of 'passing away from' the present time to indicate a point in the near future.

In some other contexts, $/ 9 \mathrm{an} /$ 'away from' replaces $/ 9 \mathrm{ala} /$ 'on' and stands for 'elevation' as follows:

(53) raDiy-a llaah-u 9an-hum wa-raD-uu 9an-hu (Qur'an 98: 8)

God well pleased with them, and they with Him.

Here, in this verse, /?ar-riDaa/ 'pleasure' surpasses all what the believers enjoy in paradise (Ibn Kathir: 4/538) that is why /9an/ 'away from' entails both 'passing away from' and 'elevation' at a time. Accordingly, elevation is considered among the inherent sub-meanings of $/ 9 \mathrm{an} /$ 'away from.'

A third inherent secondary sense of $/ 9 \mathrm{an} /$ 'away from' is the causative sense in which it replaces the particle /li-/ 'for' as exemplified in the following verse:

(54) wa-maa kaan-a stigfaar-u ?ibraahiim-a li-?abiih-i ?illaa 9am maw9idat-in wa9ad-

a-haa ?iyyaah-u (Qur'an 9: 114)

And Abraham prayed for his father's forgiveness only because of a promise he had made to him.

Obviously, the abstract sense of 'passing away from' expressed by $/ 9 \mathrm{an} /$ 'away from' justifies /stigfaar-u ?ibraahiim-a/ 'Abraham's prayer' and stands as a causative in the above context.

The fourth secondary sense of $/ 9 \mathrm{an} /$ 'away from' is to mean 'by means of'. Hassan (1996: 2/514) cites the following example:

(55) ramay-tu 9an il-qaws-i

I shot by the bow.

$19 \mathrm{an} /$ 'away from', in this example, expresses the means or the instrument used in fulfilling the verb. This sense is also inherent because when we shoot, the arrow leaves the bow and passes away from it. So, $/ 9 \mathrm{an} /$ 'away from' simultaneously expresses both 'passing away from' and the means or tool of the action fulfillment.

The fifth secondary sense of /9an/ 'away from' is to indicate 'instead of' or 'substitute for' which appears in the following verse:

(56) wa-ttaquu yawmal laa tajzii nafs-un 9an nafs-in šay?-aa (Qur'an 2: 48)

Then guard yourselves against a day when one soul shall not avail another. 
Obviously, /9an/ 'away from' in (56) states that on the Day of Judgement, the punishment of one soul will not exceed it to another. That is to say no 'passing away from', for whatever it might be the reason, is valid. Yet, this idea of denied 'passing away from' is what links this secondary sense of $/ 9 \mathrm{an} /$ 'away from' to the primary sense.

The sixth secondary sense of $/ 9 \mathrm{an} /$ 'away from' is that in which $/ 9 \mathrm{an} /$ 'away from' alternates with /mina/'from' which indicates the source or beginning of something. The following verse presents an example:

(57) ?ulaa?ika llaðiina nataqabbal-u 9an-hum ?aћsan-a maa 9amil-uu (Qur'an 46: 16)

Such are they from whom We shall accept the best of their deeds.

In (57), /nataqabbal-u 9an-hum/ means /nataqabbal-u min-hum/ because the verb /taqabbal-a/'to accept' collocates with /mina/'from' according to the following verse:

(58) rabb-a-naa taqabbal min-naa ?inna-ka ?anta s-samii9-u l-9aliim (Qur'an 2: 127)

Our Lord! Accept (this service) from us: for Thou art the All-Hearing, the All- Knowing.

However, the use of /9an-hum/ in (57) is significant as it entails two meanings at the same time: the first is the sense of 'beginning' or 'source' of something and the second is the abstract sense of 'passing away from' which is implied in the idea of the good deeds being passed away from the believers and accepted by Allah. And this is how this sense is to be considered inherent.

The seventh secondary sense of $/ 9 \mathrm{an} /$ 'away from' is that in which $/ 9 \mathrm{an} /$ 'away from' alternates with /bi-/ 'of' as follows:

(59) wa-maa yanTiq-u 9ani l-hawaa (Qur'an 53:3)

Nor does he say (aught) of (his own) Desire.

What Prophet Muhammad says is only Divine Inspiration that exceeds or rather passes away from the limits of personal desire. Again, this abstract sense of 'passing away from' links the seventh secondary sense of $/ 9 \mathrm{an} /$ 'away from' to its primary sense.

The eighth secondary sense of /9an/ 'away from' is that in which it alternates with / fii/ 'in' to indicate the abstract sense of 'containment' as follows:

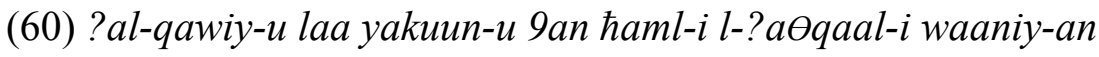

The strong man does not hesitate in carrying heavy burdens.

In the above example, $/ 9 \mathrm{an} /$ 'away from' means / fii/ 'in' and the reason it alternates with /fii/ 'in' in this context is that the active participle /waaniy-an/'hesitant' implies the meaning of the verb /tahaawan-a/ 'to neglect' which collocates with /fii/ 'in.' Here, /waaniy-an 9an/ equals Imutahawin-an fii/ and both of them imply the primary sense of 'passing away from' rendering the eighth secondary sense of $/ 9 \mathrm{an} /$ 'away from' inherent. 


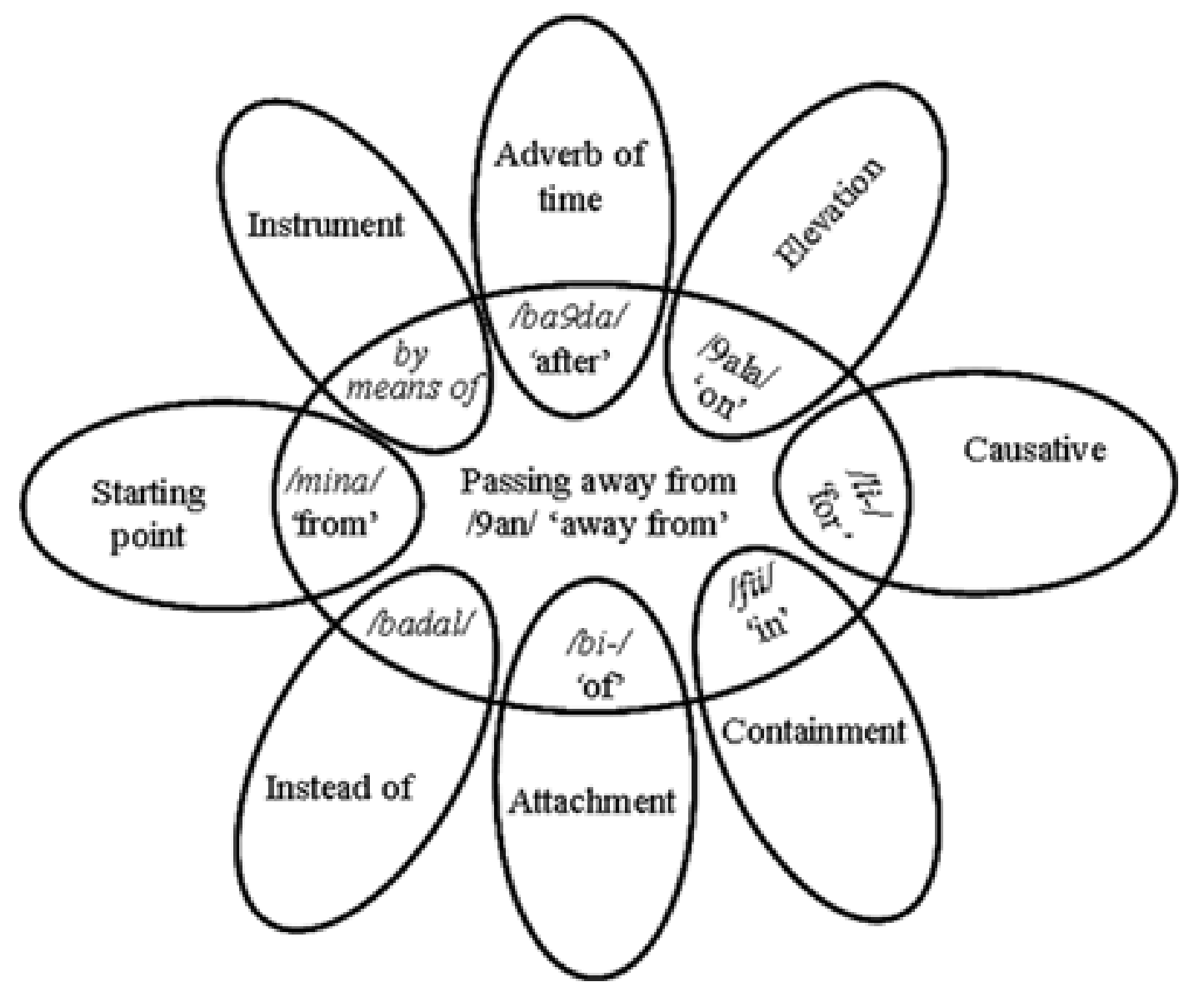

Figure 4. The primary and secondary senses of $/ 9 \mathrm{an} /$ 'away from'

\section{Conclusion}

The present study is mainly intended to discuss the polysemous nature of some Arabic prepositions. It stresses the links between the primary and secondary senses of these prepositions and proves the networking relationship between these senses with the help of figures and Arabic examples. It presents five prepositions with their various meanings. Every preposition entails a number of senses, one is primary and the others are secondary. The primary sense is what links all these senses together in a network of related meanings. For example, /mina/ 'from' primarily stands for 'commencement', /? ila/ 'to' for 'termination', /fii/ 'in' for 'containment', /9ala/ 'on' for 'elevation' and $/ 9 \mathrm{an} /$ 'away from' for 'passing away from.' However, these primary senses represent the linking frame that comprises the other secondary senses within its range.

The secondary senses of /minal 'from' are the meanings of a 'partitive particle', a 'particle indicating the genus', a 'redundant particle for confirmation', a 'causative particle', in addition to the meanings of 'containment', 'instead of', 'passing away from', 'elevation', 'by means of', and 'swearing by God'. /?ila/ 'to' has four secondary senses which are the meanings of 'company', 'containment', 'specification', and as a partitive. /fii/ 'in' has seven secondary senses which are the meanings of 'company', 'elevation', 'termination', 'measurement', 'attachment', a 'causative particle', and a 'partitive particle'. /9ala/ 'on' also has five secondary senses which 
are the meanings of 'containment', 'passing away from', 'company', a 'causative particle', and a 'partitive particle'. And finally, /9an/ 'away from' has eight secondary senses which are the meanings of 'elevation', 'attachment', 'containment', 'commencement', a 'causative particle', 'by means of', 'instead of', and the meaning of /ba9da/ 'after' (an adverb of time).

Basically, Arabic prepositions alternate with one another for rhetorical purposes. This alternation is made possible by means of /?at-taDmiin/ 'implication' as when a verb implies the meaning of another and consequently collocates with its same preposition or even acquires its same behaviour regarding transitivity or intransitivity.

\section{References}

Al-Hilâli, Muhammad Taqî-ud-Dîn, \& Khân, Muhammad Muhsin (Trans.) (1417 H). ?al-qur'an-u l-kariim wa-tarjamat-u ma9aaniih-i ?ila l-lugat-i l-inkliiziyyah [Translation of the Meanings of the Noble Qur'an In The Eglish Language]. Madina: King Fahd Complex for the Printing of the Holy Qur'an.

Ali, Abdullah Yusuf. (1938). The Holy Qur'an: Translatin and Commentary. (3rd ed.). Beirut: Dar Arabia.

Al-Maliqi, Ahmed Ibn Abdel Nour. (1394 H). RaSF Al-Mabani [Consolidating Costructions]. Verified by Al-KharraT, Ahmed. Damascus: Arabic Language Academy.

Al-Rumani, Abul-Hasan Ali. (2008). The Meanings of Particles [Ma9ani Al-Huruuf]. Verified by Shalabi, Abdel-Fattah. Beirut: Dar wa Maktabat Al-Hilal.

Cachia, Pierre. (1973). The Monitor: A Dictionary of Arabic Grammatical Terms. Beirut: Dar al-Qalam Press Co.

Comrie, Bernard. (1991). On The Importance Of Arabic For General Linguistic Theory. In Bernard Comrie, \& Mushira Eid (Eds.), Perspectives On Arabic Linguistics III (pp.3-30). Amsterdam/Philadelphia: John Benjamins Publishing Company.

Eisaa, Abdel Nasser Mahmoud. (2011). At-ta9aqub bayna Huruuf Al-Ma9ani [Alternations of Particles]. Bulletin of the Faculty of Arts, Assiut University, 40, 368-480.

Gadalla, Hassan. (2008). Comparative Morphology of Standard and Egyptian Arabic. Muenchen, Germany: Lincom Europa.

Hassan, Abbas. (1996). An-Nahw Al-Waafi [Comprehensive Syntax] 4 Vols. (13th ed). Cairo: Dar Al-Ma'aarif. Volume 2.

Hassan, Abbas. (2004). An-Nahw Al-Waafi [Comprehensive Syntax] 4 Vols. (15th ed). Cairo: Dar Al-Ma'aarif. Volume 1.

Haywood, J. A., \& Nahmad, H. M. (1982). A New Arabic Grammar Of The Written Language. Cambridge and Massachusetts: Harvard University Press.

Ibn Aqiil, Bahaa Al-Din Abdullah. (2003). Sharh Ibn Aqiil 9ala Alfiyyat Ibn Malik [Ibn Aqiil's Explanation of Ibn Malik's One Thousand Lines]. 2 Vols. (A New Revised Edition); 
Beirut: Al-Maktaba Al-ASriyyah.

Ibn Kathir. (no date). Tafsiru l-Qur'an Al-AZim [The Interpretation of the Glorious Qur'an]. 4 Vols; Cairo: Heritage Books Publishing House.

Ibn ManZur. (1981). Lisanu Al-Arab [The Tongue of the Arabs]. 6 Vols; Cairo: Dar Al-Ma'aarif.

Lyons, John. (1977). Semantics. 2 Vols; Cambridge: Cambridge University Press. Vol 2.

Rashid, Al-Sadiq Khalifa. (1996). Dawr Al-Harf fii Adaa? Ma9na Al-Jumlah [The Role of the particle in Sentence Meaning ]. Bani Ghazi: Qar Yunis Publications.

Tyler, Andrea, \& Evans, Vyvyan. (2003). The Semantics of English Prepositions: Spatial Scenes, Embodied Meaning and Cognition. Cambridge: Cambridge University Press.

Wright, William. (1964). A Grammar of the Arabic Language. 2 Vols. (3rd ed). Cambridge: Cambridge University Press. Vol 2.

Appendix. Symbols used in the phonemic transcription of Arabic forms

A. The consonants of Standard Arabic

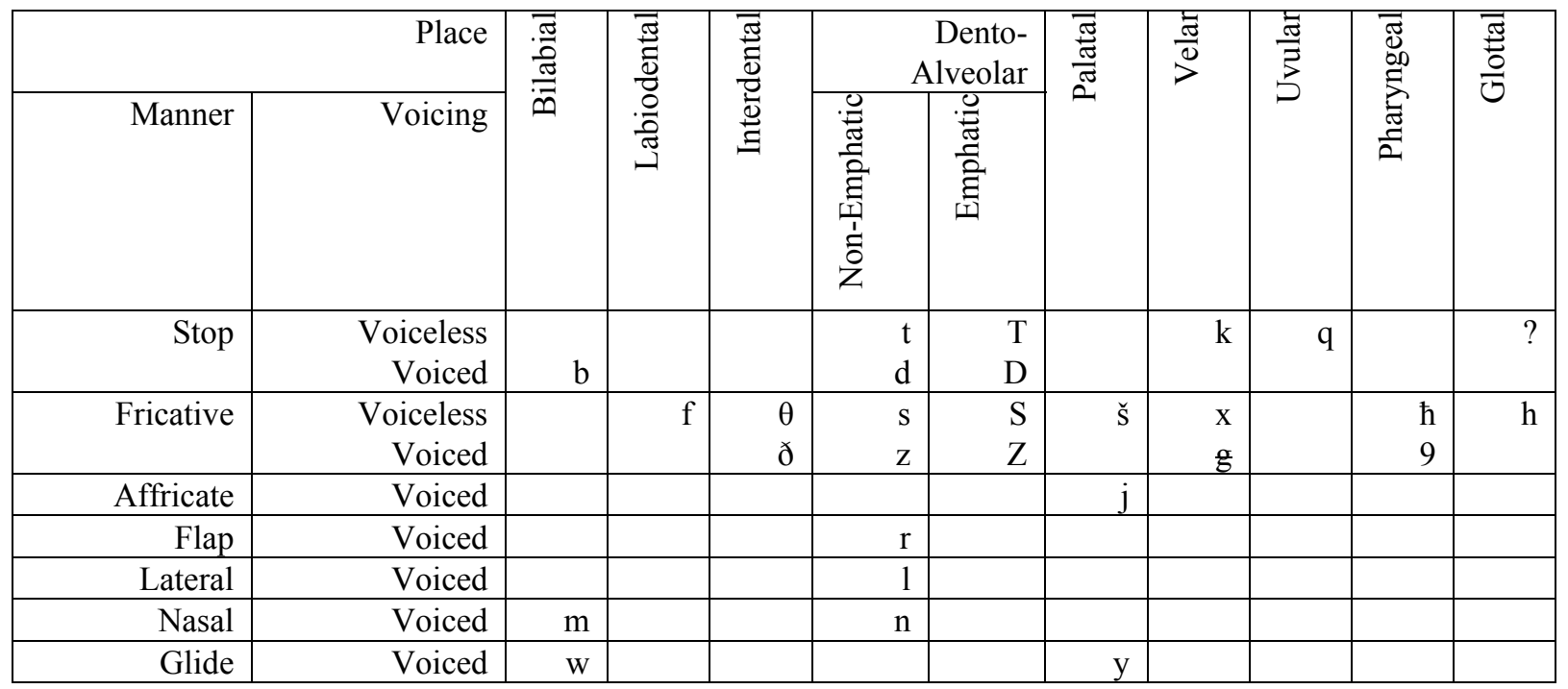

B. The vowels of Standard Arabic

\begin{tabular}{|r|r|r|r|r|r|r|}
\hline & \multicolumn{9}{|c|}{ Short } & \multicolumn{3}{|r|}{ Long } \\
\cline { 2 - 7 } & Front & Central & Back & Front & Central & Back \\
\hline High & $\mathrm{i}$ & & $\mathrm{u}$ & $\mathrm{ii}$ & & $\mathrm{uu}$ \\
\hline Mid & & & & & & \\
\hline Low & & $\mathrm{a}$ & & & aa & \\
\hline
\end{tabular}

Note: The two tables are adapted from Gadalla (2000). 